\title{
The Close Proximity of Christ to Sixth-Century Mesopotamian Monks in John of Ephesus' Lives of Eastern Saints
}

\author{
by MATTHEW HOSKIN \\ University of Edinburgh \\ E-mail: matthoskin@yahoo.ca
}

The Byzantine holy man and cult of saints are often seen as evidence that Christ had become the inaccessible Pantokrator. In this article, such assertions are challenged by a close reading of John of Ephesus' Lives of eastern saints, where many monks are shown to be very close to Christ, even in references to him as divine. Viewing hagiography as literature of exhortation and example, Christ's proximity to John's monks is seen as available to all Miaphysite Christians. This analysis is also important for investigating the spirituality of the early generations of Miaphysites, painting them as more than polemicists.

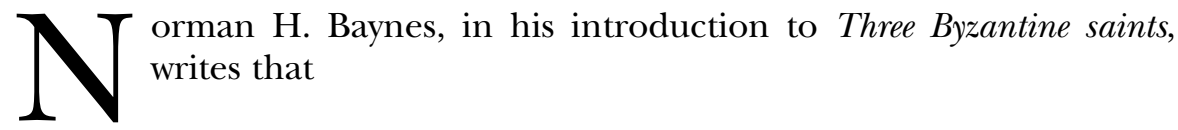

To the East Roman Christ had become the Pantokrator, the all-powerful Sovereign, throned in glory. The figure of the Christ as it was represented in the mosaics of Byzantine churches was so majestic and remote that common folk felt that they needed a mediator who would represent them in the courts of Heaven. ${ }^{1}$

This view of a distant, unapproachable Christ is not unique to Baynes, ${ }^{2}$ and has found its solution in the idea that the saints are mediators between the ordinary Christian and the distant, all-powerful Christ. This article argues

${ }^{1}$ E. Dawes and N. H. Baynes, Three Byzantine saints, Oxford 1948, p. xi.

${ }^{2}$ Cf. H. Chadwick, 'Eucharist and Christology in the Nestorian Controversy', JTS n.s. ii $\left(195^{1}\right), 145^{-64}$ at pp. 163-4. P. Brown makes similar statements in The world of late antiquity, London 1971, 37, 101-2, but not in The cult of the saints: its rise and function in Latin Christianity, Chicago 1981. 
that this is incorrect, ${ }^{3}$ and that we should turn to hagiographical writings to discard this false representation. A focus on the hagiographical work of John of Ephesus $\left(5^{\circ} 7-86\right)$ demonstrates that Christ is often, in fact, very close to the early Byzantine Christian - a closeness exhibited by other monastic writers scattered throughout the footnotes to this paper, both Chalcedonian and anti-Chalcedonian, Syriac, Greek, Coptic and Latin. Of course, if Christ were in close proximity to Christians, and Baynes's interpretation is incorrect, it is inevitable that that would be the place to find it. Therefore, before turning to the evidence for Christ's close presence in John of Ephesus' Lives of eastern saints, a brief consideration of hagiography more generally and its usefulness for discerning the spirituality of 'ordinary' Christians is in order.

The Byzantine tradition of monastic hagiography stems mainly from the Life of St Antony published by Athanasius in the fourth century. 4 The purpose of hagiography seen here is not just the exaltation of one's heroes; it also has a devotional purpose, seeking to edify the reader and draw him or her up to greater heights of holiness, to draw the reader to the worship of God, to encourage those fighting for holiness, to help make believers into the image of Christ - as in the Life's prologue: 'For me, it is a great profit and help even to just remember Antony. And I know that you also, after you have heard me ... will wish to strive after his purpose. For the life of Antony is a sufficient example of asceticism for monks.' 5 The feats of the holy man or woman are not recounted for the reader simply to stand in awe, but rather to encourage the reader in the belief that such feats are possible for him or her as well. ${ }^{6}$ This is clear from the programmatic statements made by the hagiographers themselves. These writers are indeed monastic, but Volker Menze's contention that monastic writings do not reflect 'popular' piety,7 given the role that

3 For a fuller discussion see also M. Dal Santo, 'The God-protected empire? Scepticism towards the cult of saints in early Byzantium', in P. Sarris, M. Dal Santo and P. Booth (eds), An age of saints? Power, conflict, and dissent in early medieval Christianity, Leiden 201 1, 129-49. This scepticism shows that the saints did not entirely take the place of Christ as intercessor in popular piety.

4 Even if Athanasius did not write the Vita Antonii, he approved it: T. D. Barnes, Early Christian hagiography and Roman history, Tübingen 2010, $165^{-70 .}$

5 Athanasius, Vita Antonii, prologue 3, author's translation; cf. Theodoret of Cyrrhus, Historia religiosa, prologue; Cyril of Scythopolis, Vita Euthymii 1.8.13-19; John of Ephesus, Lives 8, PO xvii.124-5.

${ }^{6}$ A similar argument is made by S. P. Brock and S. A. Harvey in Holy women of the Syrian Orient, Berkeley-Los Angeles 1987, 13-15, 18-19. See especially the statement at p. 19 that 'The audience cannot escape their own complicity in the demonic or their call to the holy ... all are called to account for their own lives.'

7 V.-L. Menze, Justinian and the making of the Syrian Orthodox Church, Oxford 2008, 10 ; cf. the contrasting view of W. H. C. Frend, The rise of the Monophysite movement, Cambridge 1972,79 . 
monastics themselves play in popular devotion, is not acceptable. This is clear in the letters sent by laypersons to Barsanuphius and John of Gaza in the 5 oos; in the numerous miracle stories recounted by John Rufus' Plerophoriae earlier that century in both the lay and monastic communities; and, time and again, in the role of monks in popular devotion throughout late antiquity. ${ }^{8}$ Furthermore, hagiography itself often has a built-in lay audience because of its liturgical use, thus bridging monastic and lay devotion.

John of Ephesus is the earliest Syriac historian.9 As a teenager, he moved to Amida, on the Tigris River, in the province of Armenia IV, after the death of Maro the Stylite, ${ }^{10}$ in whose monastery he had lived since he was a small child. ${ }^{11}$ He continued to live the monastic lifestyle in Amida. Because of imperial opposition to Miaphysitism, he left Armenia IV for Palestine, whence he continued to Constantinople where Justinian looked out for his interests and sent him to convert the pagans of Asia Minor. Presumably he converted them to Miaphysitism. Jacob Baradaeus, the wandering Miaphysite bishop who was then actively consecrating alternative bishops, ${ }^{12}$ consecrated him bishop of Ephesus. He spent more time in Constantinople than Ephesus, however, involving himself in the extirpation of idolatry in the capital. In $5^{6} 5$ Justinian died, and starting in 571 there was a persecution of Miaphysites, which involved John's imprisonment and banishment. In the end, he was imprisoned at Chalcedon where he died. He wrote an Ecclesiastical history and the Lives of eastern saints; it is the latter, his hagiographical work, which is the focus of this article. The purpose of the Lives of eastern saints is to present the lives of holy men and women of the Miaphysite faith whose stories give glory to God and can bolster the faith of the persecuted and scattered Miaphysite community throughout the Eastern Empire.

John of Ephesus is a fitting choice because he is of the first generation of bishops in what would become the Syrian Orthodox Church. Furthermore, John of Ephesus is not much read as a devotional author himself. He is

${ }^{8}$ Monastic activity in popular lay spirituality is presented in the classic paper by P. Brown, 'The rise and function of the holy man in late antiquity', Journal of Roman Studies lxi (1971), 80-101. However, Brown emphasises too strongly the intercessory role of the holy man faced with an inaccessible God; he does go some way towards redressing the imbalance in Authority and the sacred: aspects of the Christianisation of the Roman world, Cambridge 1995, 6o-2.

9 Biographical information for John comes from E. W. Brooks: $P O$ xvii, pp. iv-vi.

${ }^{10}$ As John tells us himself: $P O$ xvii. 84 .

${ }^{11}$ Lives 4, PO xvii.64; this is the culmination of the story of John's being miraculously raised from the dead by Maro: $P O$ xvii.6o-4.

${ }^{12}$ For information on Baradaeus see John's Lives 49, $P O$ lviii.69o-7, as well as the account spuriously attributed to John in $P O$ xix.228-68. See also Pseudo-Zachariah Rhetor, Historia ecclesiastica 10.1 2, and Frend, Rise of the Monophysite movement, 284-8. 
frequently read for his usefulness to historians; ${ }^{13}$ and his text is open to textual criticism. ${ }^{14}$ However, the Lives of eastern saints is a text that is rarely interpreted in its own right beyond the excellent monograph of Susan Ashbrook Harvey, Asceticism and society in crisis. ${ }^{15}$ Peter Plank has approached the question of devotion to Christ from a different angle in his reading of John of Ephesus, chapter $5^{2}$, considering the role of imitatio Christi in Syriac asceticism and the cultural context of fools for Christ who pretend to be mimes. ${ }^{16}$ This article, then, is not only a case study of hagiography as a source for the close proximity of Christ to monastics in the Justinianic era at large, but a contribution to the study of an author rarely interpreted according to his own ends. Finally, when the different roles of Christ and the titles used for him by John are examined, we see John as linked backwards to the earliest surviving Syriac tradition, laterally to the contemporary Syriac author Jacob of Serugh, and forwards into the Syriac future, to Isaac of Nineveh. These roles and titles are analysed in an ecclesiological context by Robert Murray in Symbols of Church and kingdom; while the time period and focus of this paper are different, the persistence in John of early Syriac traditions discussed by Murray is a reminder of the strength of local Christian thought even when more Hellenic modes of doctrinal discourse become essential to group identity.

Christ is present everywhere in John of Ephesus' Lives, for hagiography tends almost always either to be theocentric, as in Theodoret's Historia religiosa, or to be Christocentric as in many other Byzantine authors. ${ }^{17}$ John's

13 A few examples: J. J. van Ginkel, 'John of Ephesus on emperors', in R. Lavenant (ed.), VI symposium Syriacum I992, Rome 1994, 323-3; H. Leppin, 'Power from humility: Justinian and the religious authority of monks', in A. Cain and N. Lenski (eds), The power of religion in late antiquity, Farnham-Burlington, VT 2009, $155^{-64}$ at pp. 159-61; and even liturgy in R. F. Taft, 'John of Ephesus and the Byzantine chant for Holy Thursday', in Orientalia Christiana Periodica lxiii (1997), 503-9. He is also used as a source in wider histories, the most obvious example being P. Rousseau, 'Monasticism', in A. Cameron, B. Ward-Perkins, and M. Whitby (eds), The Cambridge ancient history, XIV: Late antiquity: empire and successors, A.D. 425-6oo, Cambridge 2000, $745^{-80}$ at pp. $757^{-} 9$ and passim.

${ }^{14}$ See J.J. van Ginkel, "WWence comes your holiness, father?” On the Life of Malkha and John of Asia', in G. J. Reinik and A. C. Klugkist (eds), After Bardaisan: studies on continuity and change in Syriac Christianity in honour of Professor Han J.W. Drijuers, Leuven 1999, $117-23$.

${ }_{15}$ S. A. Harvey, Asceticism and society in crisis: John of Ephesus and the Lives of eastern saints, Berkeley-London 1990.

${ }^{16}$ P. Plank, 'Mimésis Christu: zur Interpretation der 52. Heiligengeschichte des Ioannes von Ephesos $\left(5^{\mathrm{O}} 7^{-586)}\right.$ ', in P. Hauptmann (ed.), Unser ganzes Leben Christus unserm Gott überantworten: Studien zur ostkirchlichen Spiritualität: Fairy von Lilienfeld zum 65. Geburtstag, Göttingen 1982, 167-82.

${ }^{17}$ See Theodoret's De caritate appended to his Historia religiosa; the Historia religiosa was partially translated into Syriac. See also similar stories throughout the Vita Sabae of John's Judaean Greek contemporary Cyril of Scythopolis. 
Christocentrism comes out when he stops to provide the reader with his own programmatic statements. For example, he says that he wrote the Lives of John of Tella and John of Hephaestopolis 'in order to make known the graciousness of him who saved his church by his precious blood, how in this time of its distress also he set up these two pillars of light in it to comfort it' ${ }^{18}$ Christ is the Saviour, and it is he and his grace towards the saints that are the goal of John's hagiography. Similarly, John discusses why he includes the nun Susan in the Lives, writing that 'The strong power of Christ who is God, therefore ... is wont to be glorified and displayed in human weakness "in order that no flesh may boast before him".' ${ }^{19}$ John feels awkward including a woman in his collection of heroes of the faith, ${ }^{20}$ but including Susan is acceptable because of the power of Christ in her. Indeed, since women in John's view are naturally weak, they are notable vessels of Christ's power - the great things this power enables them to do speak of its greatness, not theirs. Christ's power is made perfect in weakness. For example, Maria and Euphemia are emphatically not weak, and they display great virtue and the philosophic/monastic parrhesia in front of the local men of power, confronting them, challenging them and shaming them into acts of mercy. ${ }^{21}$ Finally, one of the many reasons why greater attention should be paid to John is the fact that his female ascetics, unlike those of John the Stylite, are all historical persons. Their own distinct voices may be lacking, but they still represent the real spirituality of Mesopotamian Christian women.

\section{Perceived distance}

Although this article is about the closeness of these monks to Christ, it is undeniable that John has moments where Christ does seem distant, a majestic ruler to whom abject, obeisant worship is due - the Pantokrator of Baynes's quotation. Lives 1 tells of Habib praying to 'Our Lord Jesus Christ, whose signal and word of command governs everything that is in heaven and that is on earth', ${ }^{22}$ to prevent hail falling upon a vineyard and ruining it. ${ }^{23}$ Christ is undeniably the sovereign on high in this passage - but have not monarchs been known to mingle with their subjects, or at least been presented as doing so, as in Pacatus' Panegyric on Theodosius I? ${ }^{24}$ Nevertheless, the emperor of late antiquity was, indeed,

18 Lives $25, P O$ xviii. 540 .

19 Lives 27, PO xviii.41, quoting 1 Corinthians i.29.

${ }^{20}$ Ibid. $P O$ xviii. $54^{1-2}$. Note the discussion of his ambivalence towards women in Harvey, Asceticism and society in crisis, $117-33$.

${ }^{22}$ Lives 1, PO xvii. 13. ${ }^{21}$ Lives 12, $P O$ xvii.166-86.

24 Pacatus discusses how Theodosius dismissed his guards and went about like 4. ordinary senator: Panegyric 47.3. There is also the account of the Caesar Gallus going 
more the image of Justinian on the walls of San Vitale in Ravennamajestic, distant, semi-divine. ${ }^{25}$ John later has Maro saying 'Let us fear, and tremble, and entreat Christ our God to repel it [pride] from us by the prayers of his saints. ${ }^{26}$ In this passage, Christ is not an intercessor or even a mediator for his people - he is God himself, and the saints have taken on the intercessory role as Christ repels pride from his monks. ${ }^{27}$ Maro, however, presents an interesting case. He spent his life living in a tree before taking his brother Abraham's more public role as a stylite. None the less, he continued to play the misanthrope and was a reluctant intercessor. Even if Christ's holy ones in heaven were becoming his intercessors, Maro's life makes it clear that some of those on earth were not at least, not willingly. ${ }^{28}$

Christ furthermore receives their worship, as in Abraham the Recluse's ceaseless prayer, 'Glory to the Father and to the Son and to the Holy Spirit Halleluyah!' 29 None the less, too much should not be made of this Trinitarian doxology representing a distant Christ; such and similar doxologies were already a regular feature of Christian worship in the fourth century, $3^{\circ}$ although their 'Arian' forms were careful not to make the Son equal to the Father..$^{1}$ When the monk Simeon prays to Jesus he refers to him several times as Lord $(M R)$ and once, while in fact quoting a Psalm, to him as $M R$ ', the form of the Syriac word for 'Lord' reserved in the Peshitta for the divine Name. $3^{2}$ Christ is thus God, no great news

incognito in Antioch in Ammianus Marcellinus, Res gestae 14.1.9 with a reference to the third-century Emperor Gallienus at Rome.

${ }^{25}$ In stark contrast to Theodosius on foot amongst Roman senators is the proskynesis required not only by Justinian but by Theodora as well, of men of all ranks, as related by Procopius, Historia arcana 15.15 .

${ }^{26}$ Lives 4, $P O$ xvii. 77.

${ }^{27}$ For the whole story see $P O$ xvii. $72-7$.

28 For more analysis of Maro and other misanthropic saints who challenge Brown's portrait of the function of the holy man see M. Whitby, 'Maro the Dendrite: an antisocial holy man?', in Michael Whitby, Philip Hardie and Mary Whitby (eds), Homo viator: classical essays for John Bramble, Bristol 1987, 309-1 7.

${ }^{29}$ Lives 7, PO xvii.122. He prayed it even through the night, prostrating himself all the while. This does not, of course, mean that the second person of the Trinity was necessarily distant from Abraham. Perhaps this ceaseless prayer was a means of drawing nigh to Christ.

$3^{\circ}$ Christ is referenced as God throughout Ephrem's Hymns on the nativity; he very clearly receives praise in the opening of Hymn on the nativity 2, for example. For Ephrem's affirmation of Christ's divinity against Arianism see S. Brock, The luminous eye: the spiritual world vision of Saint Ephrem the Syrian, Kalamazoo 1992, 24. See also the divine titles of Christ in earliest Syriac in the Acts of Judas Thomas, Odes of Solomon, Aphrahat, Ephrem, and the Manichaean Psalms besides the Macarian homilies listed by Robert Murray in Symbols of Church and kingdom: a study in early Syriac tradition, Cambridge $1975,354^{-6}$ at table III.

$3^{1}$ See the famous discussion in the opening chapters of Basil of Caesarea, De spiritu sancto.

$3^{2}$ Lives 5, PO xvii. 100. 
concerning Miaphysite devotion, though; and no great concern for Christ's proximity to John's monks. Jesus is also the judge, 33 most notably at the end of days 34 but also in this life, a fact that should instil a drive to live righteously if the final judgement does not. ${ }^{35}$ Finally, in the eucharist, the misanthropic Maro the Dendrite remarks to his followers, 'See ... what rabutha we take upon our tongues. ${ }^{36}$ The word rabutha refers to greatness, eminence, pre-eminence-E. W. Brooks renders it here as 'majesty'. So, indeed, Christ as God can seem distant. Yet even when Maro speaks of rabutha, it is the eucharist; what is closer to the monk than the food he eats?

\section{Closeness}

Christ as God can come very close to John's monks, and not just in the eucharist. He is the source and power of their miracles, for one thing. ${ }^{37}$ When there is a great miracle of bread, John does not attribute this to the holy man, but instead calls to mind Christ feeding the multitudes. $3^{8}$ Furthermore, since Jesus is Lord and God, he is trustworthy, as when Sergius says, 'I trust in our Lord Jesus that I shall now build a monastery indeed here', 39 a task at which he is successful despite demonic opposition. Christ the God is also necessarily Christ the Saviour: $4^{\circ}$ he is cited thus in John of Ephesus several times. For example, Thomas the Armenian, about to be driven from his cell during persecution under Ephrem of Amida, says, 'I am not bound by anything else except by Jesus my God by whose name I was saved.' $4^{1}$ Simeon the Mountaineer, when he finds priestless but baptised Christians, who care not for the eucharist or Christian life, living in the mountains where he has chosen the anchoretic way, preaches to them about Christ the God who is creator and ruler of all and who

33 Cf. Vita Theodori Syceotae 148. Note that the Roman emperor was himself a judge; the heavenly throne room was often imagined by the late antique mind as being akin to the emperor's court: Brown, The world of late antiquity, 101-2, and The cult of the saints, 62-3. This is corroborated by the papyrus edited in A. H. M. Kessels and P. W. Van der Horst: 'The vision of Dorotheus (Pap. Bodmer 29): edited with introduction, translation and notes', Vigiliae Christianae xli (1987), 313-59.

34 Lives 3, 4, PO xvii.45-6, 66-7. Both of these passages deal with Matt. vii.22-3.

35 Recall the magistrate above whose house was consumed by fire: Lives $4, P O$ xvii. $72-7$.

${ }_{3}^{6}$ Ibid. $P O$ xvii. 76 .

37 This can be seen elsewhere as in Cyril of Scythopolis, Vita Sabae 46.137.1-4 where Christ turns vinegar into wine. See also Vita Theodori Syceotae 61. The sign of the cross can also perform miracles, as in Theodoret, Historia religiosa IX.5, 7 .

${ }^{8}{ }^{8}$ Lives $35, P O$ xviii.614.

39 Lives 5, PO xvii.107.

$4^{\circ}$ This fact is the driving force behind all Christological controversy from Nicaea onwards. Thus the famous dictum of Gregory of Nazianzus, ep. li: 'What has not been assumed has not been healed.'

$4^{1}$ Lives 21 , PO xvii.296. See also Lives 3, PO xvii.42. 
became man to save them here and now. $4^{2}$ Christ as God is close to his followers, then - through them, he performs miracles, and trust in him is able to establish monasteries and save souls.

As true God, Jesus is 'true King' and gives monks direct orders that are above those of earthly kings. He is thus the master of the monks, almost a heavenly abbot if you will; he commands and the monks obey, as can be seen in the life of $Z^{\prime}$ ura. When Justinian wishes to visit him, Z'ura refuses him entry on the grounds that his rule of life does not allow him to receive visitors in Lent - and his rule of life is authoritative even for the emperor because it was commanded to him by Christ.43 In Lives 14, John asks Abbi for advice, and Abbi responds, 'Jesus your Lord tells you here and shows you what is the great and first commandment' 44 - here, as master, Christ is also teacher and Lord. Christ the master has also commanded his followers to take up their cross and follow him, a command that John's monks obey in taking up the ascetic life. 45 Christ comes as close to these monks as an earthly abbot or writer of a monastic rule. As heavenly abbot he is also the teacher of John of Ephesus' monks through word and example.

Abraham the Recluse shows how mighty a teacher Christ is. At the age of sixty, having lived a life in the world, Abraham hears the teachings in Mark x.29-30 and Matthew x.38 about renouncing this world, including all familial relationships. $4^{6}$ These teachings compel him to take up the solitary life, saying, 'What have I gained either from children or from wife, or from the whole world, except that I have consumed my life in it in vanity, and idly wasted my moments, and passed my days evilly?' 47 The Christ of the monks implicitly endorses the ambivalence towards marriage displayed by Abraham in this passage, since his teachings compelled Abraham to enter the solitary life, leaving behind his entire family and former lifestyle. Christ becomes not only the teacher of monks individually, but is the teacher of celibacy itself. Later on, Abraham draws hope from Jesus'

$4^{2}$ Lives 16, $P O$ xvii.231.

43 Lives 2, $P O$ xvii.28. Christ directly giving Z'ura his rule of life parallels the 'Rule of the Angel' in Jerome, Regula Pachomii 1, and Cassian, Institutes 2.4; cf. also Besa, The life of Shenoute 94, 95, for Shenoute's encounters with the prophets themselves. In the seventh century Isaac the Syrian refers to monks having been taught by angels: Ascetic discourse $5 \cdot 35^{-9}$, in Mar Isaacus Ninivita de perfectionis religiosa, ed. P. Bedjan, Paris $1909,65^{-7}$.

$44 P O$ xvii. 219.

45 Lives $21, P O$ xvii. 288.

$4^{6}$ Although the scriptural passages are different, note the parallel with Vita Antonii 2.3. For further references to Christ as teacher, revealer, explainer, speaker, illuminator, master of the wise and confirmer of truth in earliest Syriac literature see Murray, Symbols of Church and kingdom, 357 .

47 John of Ephesus, Lives 7, PO xvii. 119 . On the Syrian rejection of marriage as a prerequisite for holiness see S. P. Brock, 'Early Syrian asceticism', Numen xx (1973), 1-19 at pp. 6-7, 10-11. 
parable of the workers, for he himself has joined the labour - the ascetic lifestyle - late in life..$^{8}$

Elsewhere, an enigmatic statement from Addai points to Christ as the greatest teacher and spiritual father of all monks. When John and a friend who have been hunting Addai through the mountains for a considerable time finally corner him, he says, 'Do we then, pray, seek another greater than Jesus to speak with us or to admonish us? And, if we do not obey him, if a man rise from the dead and speak, how shall we obey him?' 49 Here, Addai points to Jesus who is to be sought, and the monk is to obey him. This relationship reflects the life of absolute obedience that monks led with respect to their monastic elders as part of their spiritual formation throughout the Byzantine world. $5^{\circ}$ Obedience was meant to bring great spiritual benefit to the spiritually younger monk and was often a very close relationship..$^{1}$ Jesus, then, is more to be sought and obeyed than earthly saints, whether the best of abbots or spiritual fathers. In chapter 11 John addresses the over-zealous monk Harfat with what he calls 'God's commandments'. $5^{2}$ Harfat had been engaging in excessive acts of asceticism without discretion, and John was concerned that he would not be able to endure and that he would thereby ruin his health.53 All of 'God's commandments' in this instance are quotations from Christ in the Gospels, a reminder that Jesus is the ultimate monastic teacher, the one who advises the monks on discretion and on how best to live their lives.

John of Ephesus also sees Christ as an example of humility for the monks to follow. In chapter 14 Abbi tells John to be humble, saying, 'He has ... in his own person shown you humility',54 and humility is a universally important monastic virtue. 55 Christ also teaches by example in the Life of Simeon.

$4^{8}$ Lives 7, PO xvii. 120.

49 Lives 8, PO xvii.1 34; cf. Barsanuphius and John, ep. cxcvi.25-7.

$5^{\circ}$ Cf. Cassian, Institutes 4.10 . On the importance and the characteristics of the role of the elder in early monasticism see L. Dysinger, 'The basis of spiritual exercise and spiritual direction', in E. López-Tello García and B. S. Zorzi (eds), Church, society and monasticism, Rome 2009, 437-42. Obedience is the foundation of the Asketikon of Basil of Caesarea; see especially Longer rule 41 .

$5^{1}$ John gives us such a relationship in Lives $5, P O$ xvii. $84^{-111}$.

$5^{2}$ Lives 11 , PO xvii.165.

53 On discretion see Cassian, Collatio 2, and Barsanuphius and John, ep. xxiii, esp. lines $25^{-6}$. Theodoret expresses similar concern in Historia religiosa 21.8, 29.5. On the types of extreme lifestyles of Syro-Palestinian monks see Evagrius Scholasticus, Historia ecclesiastica 1.21. Such lack of discretion on the part of Syrian ascetics is seen as part of their monasticism as having 'developed anarchically' in Frend, Rise of the Monophysite movement, 88-9. However, Brock shows that the origins of Syrian asceticism point to roots within the Christian culture of the Syrian world: 'Early Syrian asceticism'.

54 Lives 14, PO xvii.219.

55 See, for example, Apophthegmata patrum, Antony 7, Arsenius 36, Daniel 3; Isaac of Nineveh, Ascetic discourse 4.66 in Mar Isaacus Ninivita de perfectionis religiosa, $5^{1-2}$; Cyril of Scythopolis, Vita Sabae 16.100.15-21 and 35.120.22-3; and somewhat later in Sinai, 
Whenever Simeon received a guest, 'he himself would run and prepare a footpan and bring water, and would prepare a towel and put it round his loins, in the manner which our Lord also taught [emphasis added]; and thus he would wash them whether they were one or many, not allowing them to speak nor to refuse'.$^{6}$ Here the example of Christ's humility and service to others in foot-washing is being taken literally by the holy man. Such literalism is also a common feature of ancient asceticism, especially in some of its more extreme Syrian manifestations. 57 John's way of interpreting Christ's teaching is not out of keeping with his context; the monks he describes seek to live out to the full the teachings and examples provided by Christ in his life on earth, seeking to serve others, utilise discretion, be humble, renounce the world and, literally, wash the feet of others. Christ the teacher informs the actions of the monks, and does so quite frequently given how often the Gospels are quoted by them. He is close to them, at their side in and informing all they do, not a removed, distant, untouchable deity.

John mentions Christ the Physician in the discourse given unto him by John the Nazirite; if one lapses 'secretly or openly', he is to turn immediately to the 'gracious Physician' bearing his sin; Christ shall mercifully heal the lapsed Christian..$^{8}$ The image of the physician is a major image for Christ's action in the Christian life in both the monastic world,59 and the Syriac world more generally. ${ }^{60}$ This active role of Christ in human

John Climacus, Scala paradisi 4. Macarian homily 19 creates a chain continually linking humility-charity-meekness or humility-charity-prayer or humility-charitymeekness - prayer; homily 12.4 also sees humility as essential for citizens of the heavenly city. In Greek see Barsanuphius and John of Gaza, ep. cxix.11-15; see also epp. cclxxvii-cclxxxiii to Dorotheos, which form a series on humility.

$5^{6}$ Lives $5, P O$ xvii.86-7.

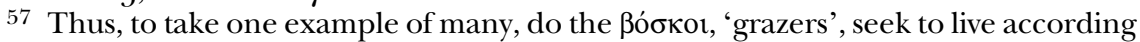
to Matt. vi.25-34, taking no care for the morrow and eating what God provides for them. More common, of course, are monks seeking continual prayer in the spirit of 1 Thessalonians v.16; some examples of this are Liber graduum 12.1; Evagrius Ponticus, De oratione 2, 88, 11; Barsanuphius and John, ep. ccccxxv; and John Climacus, Scala paradisi 28.

59 For example, Dorotheos, Instruction $11.23^{f f}$; Barsanuphius and John, ep. clxx. $5^{-7}$; Moschos, Pratum spirituale, 144; Vita Theodori Syceotae 146.

60 The image of Christ as physician is as old as the surviving Syriac tradition itself, used in the Acts of Judas Thomas, Aphrahat, and Ephrem who prefers this title for Christ above all others: Murray, Symbols of Church and kingdom, 199-203. Ephrem also uses medical imagery in discussing the sickness of heresy and schism: Murray, Symbols of Church and kingdom, 89-91. A related image is that of the medicine of life, which is older than extant Syriac literature in the Syrian Greek writings of Ignatius of Antioch, who is the first instance of the term 'medicine of immortality' for the eucharist (Eph. xx.2) - in fact, 'medicine of life' has a non-Christian Mesopotamian history: Murray, Symbols of Church and kingdom, 120. For Ephrem, Christ is the medicine of life that came down from heaven, above all in the bread and wine of the eucharist: 
life finds its biblical precedent in Matt. ix. 12 and Luke iv.18, and the image of spiritual healing - beyond numerous images in the Hebrew Bible - in James v.16; its history within Syriac Christianity goes back to its beginnings. Christ the Physician points the monk to a more process-oriented, ongoing salvation, whereas Simeon the Mountaineer's preaching of Christ crucified is about the Christ who saves people here and now. There is an interplay in monastic discourse between complementary views of salvation, that Christ saves through an immediate rescue of the human soul as well as through the ongoing processes of purification, healing and repentance. ${ }^{61}$ Related to his salvific action as Physician is Christ the Life-Giver, a reference either to his divine action in the world or to his salvation of human souls, given in the context of discussing the fate of the damned. ${ }^{62}$

The creation of a monastic foundation through the expulsion of demons is also present in John of Ephesus, a common part of the motif of the Christaided battle with demons, a motif that goes back to the earliest monastic literature, such as the Vita Antonii. ${ }^{63}$ However, the antiquity of the motif does not mean that John depends upon the Vita Antonii, and it is not the sole preserve of hagiography. ${ }_{4}$ Christ aids Paul the Anchorite in John's Lives when he expels demons from a cave. ${ }_{5}$ The expulsion of demons from places, especially remote ones such as in Paul's cave, Savvas' mountaintop fortress, ${ }^{66}$ Maron's hilltop temple ${ }^{67}$ and Antony's mountain, is part of the narrative of the monks conquering the pagan world in Christ's name once the demons are expelled from populous places in

Brock, The luminous eye, 99-1 14. For Christ the Physician see also all of Macarian homily 20 as well as homilies 26.23 and $45 \cdot 3$; see Theodoret, Historia religiosa XIV.3; see also Jacob of Serugh, 'Homily on the nativity 1', lines $1075^{-7}$ in S. Martyrii qui et Sahdona, quae supersunt omnia, ed. P. Bedjan, Paris 1902, 720-74 at p. 771 (homily 6), and Homily on the Ascension of Our Lord, lines 81-4, ibid. 812 (homily 9), and for the Friday of the Passion, chapter $31, P O$ xliii.4, 627.

61 Cf. Barsanuphius and John, ep. cxix.

62 Lives 3, PO xvii.54. This title also appears in Acts of Judas Thomas and Aphrahat: Murray, Symbols of Church and kingdom, 357; cf. Vita Theodori Syceotae 72.

63 For the Syriac edition see CSCO $417,4^{18}$.

64 Demonological literature from antiquity is vast, so only a few examples should suffice. For eastern demonology in the period before Evagrius see D. Brakke, Demons and the making of the monk, Cambridge, MA 2006. John's older contemporary, Jacob of Serugh, has as the central theme of his 'Second homily on the nativity' the power of Christ's Incarnation to defeat the demons in S. Martyrii qui et Sahdona, quae supersunt omnia, 775-9o (homily 7). See also Isaac of Nineveh, Ascetic discourses 5.11 in Mar Isaacus Ninivita de perfectionis religiosa, 62. Again in Isaac of Nineveh, 'The second part', $C S C O 554^{-5}$, v.26, x.28, xIV.34; v.26 is an especially potent description of how God provides succour to those in battle with demons.

65 Lives 6, POxvii.1 1 2-16, although the reference is oblique. See also the Vita Danielis $18-19$.

${ }^{66}$ Cyril of Scythopolis, Vita Sabae 27.110.16-17.

${ }_{7} 7$ Theodoret, Historia religiosa XvI.1. See also Thalelaeus' hilltop temple outside the city in Historia religiosa XXvIII. 1 . 
the years following Constantine's conversion. ${ }^{68}$ Thus, one of John's monks is berated by Susan, reminding him that he is Christ's bondman and that Christ has already gained the victory over the demons. ${ }^{69}$ By drawing on this theme, John draws his monks into the wider world of demonic battle, itself Christocentric as early as the Vita Antonii. $7^{\circ}$ By drawing his monks into the ongoing narrative of battle against demons, John of Ephesus brings his monks close to Christ just as the earlier monks were close to Christ. $7^{1}$

In all of these examples, Christ draws nigh to John's monks in a spiritual or metaphysical way. Yet he is also present to them in the day-to-day realities of life, in the person of the stranger, the orphan and the visitor, as per Matt. xv.31-46. This view has an immediate effect upon the conduct of the monks and recurs in John of Ephesus' Lives. In chapter 5, Simeon greets all of his guests as though they were Christ bringing honour upon Simeon by visiting him, a lowly sinner..$^{2}$ In fact, Simeon feels this humility in face of Christ the stranger so greatly that even on his deathbed it causes him to weep:

'How can I do aught but weep for my wretched self, since Christ comes to me on his own feet, and I cannot rise and wash them and drink.' But I [John of Ephesus], in order that he might be comforted, was saying to him: 'Be not distressed at this, our father. When Christ wished, you washed him as much as he wished. And now his will be done. And your own will also he knows, and will not do you wrong, weep not.' But he said to me: 'He, my son, has not done me wrong and does not do wrong; but I am a doer of wrong and one who have done him wrong, and who am doing him wrong. If I had served him as I ought to have done, he would have allowed me to serve him all my life; but because I provoked him and neglected the service of his bondmen, for this reason he cast me down.' 73

Observe how close Christ was to Simeon. His is not subservience to a distant God, nor his spirituality a spirituality unto a lofty, unreachable being high in the sky, but a spirituality that drew him necessarily to his God where he could find him, in the people who came to visit him in his monk's cell. Christ is at hand and is involved in the holy man's life in this instance. We see also Christ's role as judge even now, perceived as providing a

${ }^{68}$ For the battle with demons as the archetypal event in monastic life see Brakke, Demons and the making of the monk, 3-22.

69 John of Ephesus, Lives 27, PO xviii.556-8. $\quad 7^{\circ}$ Vita Antonii 8.7-10.19.

${ }^{71}$ This battle has one of its most striking instances in the explicitly physical combat of Shenoute in Besa, The life of Shenoute 73. Theodoret also tells of his own encounter with a Syriac-speaking demon in Historia religiosa XXI. $15^{-1} 6$; other detailed combats are few in that work, but see III.9, IV.7, VI.13, XXI.18, 23-8, XXVII.1, XXVIII.1-2.

$7^{2} P O$ xvii.86ff. See also Lives $17, P O$ xvii.250-1, which describes how hospitality at the convent of Mar John Urtaya is given to people as though they were Christ, and $P O$ xviii. $596-8$, where Hala gathers food for the poor, asking, 'Who has anything to give to my Lord Jesus?'. 73 Lives 5 , PO xvii.95. 
temporal judgement on Simeon through his infirmity. None the less, he is close, as close as a visitor at Simeon's table.

Another Simeon, the Scribe of Amida, is also keen to help the blind men of his city, and would 'wait on them as if they were Jesus Christ'. 74 Similarly, Simeon the Solitary leaves his settlement without any gates, saying, 'Thus it will be open to Christ my Lord when he comes to me to enter my dwelling in the person of his bondmen simply and without impediment; that so he may grant me the blessing of his favour.' 75 Not only is Christ to be seen in the visitors, but he also sends them to Simeon. ${ }^{76}$ In chapter 12 Euphemia demands that the wealthy of the city help the poor: 'A mighty matter it is that you do toward Christ, whose property all your good things are.'77 In a later speech, she scolds those who do not help the poor, rebuking them for enjoying the good things of this life 'while God is knocked down in the street and swarms with lice and faints from his hunger'.$^{8}$ Again, then, is demonstrated how close these monks perceived Christ to be - as close as a stranger on the street, a companion at table, a poor man begging for bread.

Just as Christ is present in visitors, he is present with exiles, no doubt because he is present with his body in all places. When Addai is given the option of confessing Chalcedon or going into exile, he says that he will go into exile, for Christ himself was being driven into exile - in so doing, he remains faithful to Christ and with Christ.79 Christ is the shepherd of his 'innocent flock', ${ }^{80}$ an image he himself instituted during his earthly ministry, and one taken on by the entire Christian tradition, including monasticism. His sheep, including the monks, are Christ-bearers and Christ's bondmen; ${ }^{81}$ the persecutors of the faith drive Christ himself before them with the believers. ${ }^{82}$ Christ, then, has no part with apostate heretics. ${ }^{83}$ Christ thus takes on a variety of active roles in the lives of the monks. He is their shepherd, their helper, their champion, their physician, their witness, their example, their teacher. His presence in their lives drives their actions, guides their thoughts, and keeps them faithful. There is a

74 Lives 34, $P O$ xviii.605.

77 Lives $12, P O$ xvii. 178.
$7^{8}$ Ibid. $P O$ xvii. 179 .

75 Lives 23, PO xvii.301.
$7^{6}$ Ibid. $P O$ xvii.302.

79 Lives 8, PO xvii. 127. contemporaries of John of Ephesus, note Jacob of Serugh, 'Homily on the nativity 1', lines 1063-6, in S. Martyrii qui et Sahdona, quae supersunt omnia, $720-74$ at p. $77^{\circ}$ (homily no. 6). See also Macarian homilies $45 \cdot 3-4$.

${ }^{81}$ Lives $17, P O$ xvii.255 amongst others.

${ }^{82}$ However, John's tales of Amidene and episcopal exiles must be taken in context. As Menze argues, the Chalcedonian powers of the reigns of Justin and Justinian rarely exiled or emptied entire monasteries outside of Amida and Edessa: Menze, Justinian and the making of the Syrian Orthodox Church, 106-44.

${ }^{83}$ According to the Chalcedonian Moschos they burn in hell: Pratum spirituale 26. 
closeness of Christ in all of these examples, for each of them involves action on Christ's part in the life of the holy man in whom and through whom he works.

The final role or title to be examined is that of bridegroom. The image of Christ the bridegroom is an ancient motif in Syriac literature, with strong biblical precedents, drawn from the words of Jesus himself in the Gospels and expounded by Paul. $^{84}$ As Robert Murray has demonstrated, ${ }^{85}$ Christians together as a whole are the bride of Christ in Aphrahat, the Odes of Solomon, Acts of Judas Thomas, Ephrem and Marutha. In Hymn on Epiphany 11, attributed to Ephrem, marriage and baptism are explicitly linked through the ritual crowning common to both. ${ }^{86}$ In baptism each soul is wed individually to Christ. ${ }^{8} 7$ In the absence of the Origenist exegetical tradition that leads the West to the very personal union of Bernard of Clairvaux, the Syriac world tends to keep this image for the Church as bride, although it inevitably applies to the baptised individual members. This image appears only once in John of Ephesus' Lives, in Euphemia's deathbed speech to her daughter Maria:

My daughter, be comforted in Christ, keep yourself in purity for the Lord your Lord to whom you were betrothed; and be not distressed, for I am not deserting you (far be it from me, my beloved); but I am committing you to the Child of my blessed Lady Maria, and to the holy one herself, that by her prayers you may be preserved, and may become a temple for the indwelling of the Holy Spirit of God. ${ }^{88}$

The overall idea running through this passage is that of Christ the comforter, guardian and protector. When earthly resources, in this case Maria's mother, run out, the heavenly protector is always there. ${ }^{89}$ More specifically, Christ is Maria's husband, him to whom she was betrothed. While it was not common in Syriac for $M R$ to refer to one's husband, this could be the cause of the double reference to Christ as 'Lord' - the first is to Christ the Lord who is God, using the emphatic form $M R$ ' that is used only for the divine Name and for Christ; the second is to Christ your Lord, which could mean husband. Certainly the second use of $M R$,

\footnotetext{
${ }^{84}$ For example, Eph. v.32. It has a Syrian precedent in Macarian homily 1 2.3-5. Jacob of Serugh, 'Homily on the baptism of our redeemer in the Jordan', holds the Church as bride and Christ as bridegroom as its central theme, drawing together both baptism and marriage, in Homiliae selectae Mar-Jacobi Sarugensis, i, ed. P. Bedjan, Paris-Leipzig 1905, 167-93 (homily 8). Among his many other references to Christ as bridegroom, one of Jacob's most beautiful passages on this theme is in the 'Homily on the ascension of our lord', lines 275-8, in $S$. Martyrii qui et Sahdona, quae supersunt omnia, 8o8-32 at 821 (homily 9). $\quad 85$ Murray, Symbols of Church and kingdom, 132-42.

${ }_{86}$ CSCO clxxxvi.1 85, cited in Murray, Symbols of Church and kingdom, 140.

87 Murray, Symbols of church and kingdom, 141.

${ }^{89}$ Cf. Matt. xxviii.20.
} 
inflecting the word with the feminine singular possessive suffix, is a much more personal use of Lord. No human relationship is more intimate than that of husband and wife, so there is no closer approach of Christ to the ascetic than as husband to wife. Although John only uses this particular title and image for a nun, this does not mean that the road is not open for monks to be the bride of Christ as well; indeed, the individual soul is often presented as the bride of Christ in such literature as the Macarian homilies. $9^{\circ}$ The rhetorical significance of Christ as bridegroom would resonate more deeply with the monastic renunciation of a nun than that of a monk. Thus, it is perhaps no great surprise that John does not have his monks speaking to each other of Christ as their husband.

This article has focused upon several instances of many from one piece of writing by John of Ephesus. Similar examples could have been found in the work of various other early Byzantine writers; indeed, the notes to this article deliberately provide the reader with references to a variety (by no means exhaustive) of Byzantine and late antique spiritual writers to draw attention to the fact that John of Ephesus was not isolated in his views. One implication of this is that Christ, in practical spirituality, is as available to Miaphysites as to Chalcedonians; from the evidence of Isaac the Syrian a century later, it seems entirely likely that the Dyothelite, so-called 'Nestorians', of the Church of the East would have had a similar on-theground spirituality. Christ is not an angry, scowling, distant God looming overhead in a dome, or the radiant image of the Transfiguration in the sixth-century mosaic at St Catherine's, Sinai. Instead, early Byzantine literature brings Christ to his people, encouraging them to find him where he is, as in these saints' Lives. He is more like the other famous sixth-century icon of Christ Pantokrator, painted on wood, from St Catherine's, or the equally famous sixth- or seventh-century Coptic icon of Christ with Apa Mena, now in the Louvre..$^{1}$ If Christ is not distant to the holy men, he is not meant to be distant to the laity, either. They, like the saints, will find him in the poor, the visitor, the exile, the stranger; they, like the saints, will find him in the Scriptures, the eucharist, the prayers; they, like the saints, will find him to be close at hand and watching over them-and, while he may at times watch over them with the stern gaze of the Pantokrator, it is the gaze of one who will never leave them nor forsake them. It is the gaze of Christ the God who can be trusted by his people, calling them to lives of holiness,

$9^{\circ}$ For examples of where the image is used in the Macarian homilies for the individual soul and not simply the Church as a whole see 8.1, 1 2.5, 15.36, 25.8, 27.1-2, 33.4, 38.5, $45 \cdot 7,46.6,47 \cdot 14,17$ and $49 \cdot 4$.

$9^{1}$ For this date of the icon see K. Wessel, Coptic art, trans. J. Carroll and S. Hatton, London 1963, 172-5, and P. du Bourguet, Coptic art, trans. C. Hay-Shaw, London $1971,4^{\circ}-5$. 
not just the monks of hagiography, but the readers and hearers of hagiography, the 'common people' who encountered the saints in life. In the end Baynes's assertion - which could seem to be justified at first blush when the prominence of holy men and saints as intercessors, together with the apparent sternness of Christ in Byzantine icons, is observed - is misconceived, weakened by the programmatic statements of hagiographers and the intense closeness of Christ to the common monks of John of Ephesus' Lives of eastern saints. 